\title{
PERAN LINGKUNGAN SEKOLAH TERHADAP MINAT BELAJAR SISWA SD/ MI
}

\author{
ZAENOL FAJRI ${ }^{1}$ \\ ${ }^{1}$ Universitas Nurul Jadid, Paiton, Probolinggo \\ Email: alfajri002@gmail.com
}

\begin{abstract}
National education is organized through formal, informal and non-formal education. National education targets will be achieved if the purpose of learning achieved properly. The implementation of learning is influenced by internal and external factors. One example of internal factors is interest to learn and externals is the school environment. The school environment consists of educators and education personnel, teaching materials, fellow students and the physical environment (facilities and infrastructure). a good school environment in accordance with the standardization of education, it can increase student learning interest and facilitate the implementation of conducive learning. So that the purpose of learning can be achieved well and smoothly. In conclusion, that the influence of the school environment can have a positive impact on learning interest so that learning objectives can be achieved well and smoothly.
\end{abstract}

Keywords: school environment, interest to learn

\section{Pendahuluan}

$\begin{array}{rrr} & \text { Pendidikan merupakan usaha } \\ \text { sadar } \quad \text { manusia } & \text { untuk dapat }\end{array}$ mengembangkan potensi dirinya melalui proses pembelajaran. Pendidikan bertujuan menghasilkan sumber daya manusia yang berkualitas untuk pembangunan bangsa dan negara.
Pendidikan juga berperan penting dalam rangka mengembangkan dan meningkatkan kemajuan suatu negara.

UU No. 20 Tahun 2003 dalam Bab IV Pasal 3, menjelaskan fungsi dan tujuan sistem pendidikan nasional yaitu: Pendidikan nasional berfungsi mengemban kemampuan dan 
membentuk watak serta peradaban bangsa yang bermartabat dalam rangka mencerdaskan kehidupan bangsa, bertujuan untuk berkembangnya potensi peserta didik agar menjadi manusia yang beriman dan bertaqwa kepada Tuhan Yang Maha Esa, berakhlak mulia, sehat, berilmu, cakap, kreatif, mandiri, dan menjadi warga negara yang demokratis serta bertanggung jawab (Kemdikbud, 2003).

Tujuan sistem pendidikan nasional dapat dicapai apabila didukung oleh seluruh lapisan masyarakat. Usaha pemerintah untuk mewujudkan tercapainya tujuan pendidikan nasional yaitu dengan diselenggarakan pendidikan, baik pendidikan formal, informal maupun non formal. Sebagaimana dijelaskan dalam UU No. 20 Tahun 2003 pasal 13 ayat (1) yang berbunyi: "jalur pendidikan terdiri atas pendidikan formal, nonformal dan informal". Pendidikan formal diselenggarakan dalam bentuk sekolah dan perguruang tinggi. Pendidikan nonformal diselenggarakan di dalam masyarakat dalam bentuk kursus, TPA, dan sebagainya, sedangkan pendidikan informal merupakan jalur pendidikan keluarga dan lingkungan (Kemdikbud, 2003).

Pendidikan dasar adalah jenjang pendidikan yang melandasi jenjang pendidikan menengah. Pendidikan dasar dapat berbentuk sekolah dasar (SD) dan madrasah ibtidaiyah (MI) atau yang lainnya yang sederajat. Sardiman menyatakan bahwa pada sekolah dasar, pendidikan berfungsi sebagai pemberi bekal dasar pengembangan kehidupan, baik kehidupan pribadi maupun masyarakat (Sardiman, 2009). Pendidikan di sekolah dasar (SD) atau Madrasah Ibtidaiyah (MI) sangatlah penting bagi peserta didik, karena merupakan dasar perkembangan pengetahuan yang diperoleh peserta didik.

Dipendidikan dasar terjadi
interaksi pembelajaran antara guru 
dengan siswa, atau siswa dengan siswa. Interaksi pembelajaran disekolah biasa dilakukan diruang kelas maupun diluar kelas. Menurut (Slameto, 2013) "belajar merupakan suatu proses usaha yang dilakukan seseorang untuk memperoleh suatu perubahan tingkah laku yang baru secara keseluruhan, sebagai hasil pengalamanya sendiri dalam interaksi dengan lingkunganya." Sejalan dengan pendaptnya Fajri bahwa perolehan pengetahuan merupakan suatu proses interaksi lingkungan secara aktif (Fajri, 2010).

Seseorang dikatakan belajar jika dalam diri orang tersebut terjadi suatu aktifitas dengan lingkungannya yang mengakibatkan perubahan tingkah laku dan terjadi relatif lama. Suyono menjelaskan bahwa belajar adalah suatu aktivitas atau suatu proses untuk memperoleh pengetahuan, meningkatkan keterampilan, memperbaiki perilaku, sikap dan mmemperkokoh kepribadian (Suyono, 2011). Mengajar merupakan suatu usaha penciptaan kondisi atau sistem lingkungan yang mendukung dan memungkinkan untuk berlangsungnya proses belajar (Sardiman, 2009). Kegiatan belajar mengajar direncanakan sedemikian rupa agar dapat mencapai tujuan. Dilanjutkan dengan pernyataan Sardiman bahwa tujuan dari belajar mengajar ialah: untuk mendapatkan pengetahuan, penanaman konsep dan ketrampilan, dan pembentukan sikap (Sardiman, 2009).

Pembelajaran aktif merupakan strategi pembelajaran yang lebih banyak melibatkan peserta didik dalam mengakses berbagai informasi dan pengetahuan untuk dibahas dan dikaji dalam proses pembelajaran di kelas (Baharun, 2015). Untuk mencapai tujuan pembelajaran ada beberapa faktor yang mempengaruhinya. Faktor-faktor tersebut yaitu faktor intern dan faktor ekstern. Faktor intern yang berasal dari dalam diri peserta didik, sedangkan faktor ekstern berasal dari luar peserta didik. Salah satu faktor intern yang besar pengaruhnya terhadap belajar adalah 
gen, motivasi, minat dan lain-lain. Sedangkan untuk faktor ekstern yang besar pengaruhnya terhadap belajar adalah faktor lingkungan belajar terutama lingkungan sekolah.

\section{Lingkungan sekolah merupakan} salah satu faktor yang mempengaruhi minat belajar peserta didik Sekolah Dasar (SD)/ Madrasah Ibtidaiyah (MI). Lingkungan sekolah teridiri dari para guru, staf administrasi, dan teman-teman sekelas peserta didik serta lingkungan sekolah secara fisik. Lingkungan sekolah secara fisik seperti, sarana dan prasarana di dalam kelas, keadaan gedung sekolah dan sebagainya. "Faktor lingkungan sekolah yang mempengaruhi belajar meliputi metode mengajar, kurikulum, relasi guru dengan siswa, relasi siswa dengan siswa, disiplin sekolah, pelajaran dan waktu sekolah, standar pelajaran diatas ukuran, keadaan gedung, metode belajar dan tugas rumah" (Slameto, 2013).

Di lingkungan sekolah, peserta didik akan berinteraksi dengan sesama peserta didik, guru dan warga sekolah yang lainya. Namun masih ada beberapa peserta didik yang kurang mampu dalam berinteraksi dengan teman sebayanya ataupun dengan gurunya, karena peserta didik masih merasa malu ataupun minder. Sehingga mempengaruhi minat belajar peserta didik. Apabila hal ini tidak segera diatasi, maka peserta didik akan mendapatkan hasil belajar yang kurang optimal.

Minat belajar peserta didik juga dapat dipengaruhi oleh metode mengajar guru. Guru harus mampu menggunakan metode-metode mengajar yang menarik dan dapat mengaktifkan peserta didik. Metode mengajar yang tepat dan bervariasi akan mampu membangkitkan minat belajar peserta didik serta membantu pemahaman materi pelajaran yang disampaikan oleh guru.

$$
\text { Penyampaian materi }
$$
pembelajaran yang didukung oleh media/ alat peraga akan memudahkan peserta didik untuk memahami materi pelajaran. Media/ alat peraga di sekolah 
seperti sarana dan prasarana yang ada disekolah. Sarana dan prasarana yang kurang memadai akan mempengaruhi minat belajar peserta didik. Salah satu sarana yang berkaitan dengan minat belajar persta didik contohnya gedung sekolah. Apabila keadaan gedung sekolah kurang mendukung, maka aktivitas belajar peserta didik, akan kurang maksimal. Sesuai hasil penelitian Higgins dkk dengan judul "The Impact of School Environments: A literature review" hasil dari penelitian ini yaitu elemen fisik di lingkungan sekolah terbukti memiliki pengaruh terhadap guru dan peserta didik. Selain gedung sekolah, ada juga waktu sekolah, penggunaan waktu yang tepat akan memberikan pengaruh yang positif terhadap belajar peserta didik (Higgins, Steve. Elaine Hall, Kate Wall, Pam Woolner, 2015).

Selain interaksi peserta didik, metode mengajar, sarana dan prasarana, keadaan gedung dan waktu sekolah, maka kurikulum atau materi yang diterapkan oleh sekolah juga dapat mempengaruhi minat belajar peserta didik di sekolah. Pada umumnya di sekolah dasar ada yang menggunakan KTSP dan ada juga kurikulum 2013. Penerapan kedua kurikulum didalam pelaksanaan pembelajaran akan menuntut guru untuk menggunakan model, pendekatan, startegi metode dan teknik pembelajaran yang berbeda-beda. Sehingga dapat berpengaruh pada kesiapan peserta didik dalam menerima pembelajaran, maka akibatnya tidak jarang ada peserta didik yang mengalami penurunan minat dan hasil belajar.

Berdasarkan hasil pembahasan di atas, peneliti tertarik untuk mengkaji pemahaman lebih mendalam tentang "Peran Lingkungan Sekolah terhadap Minat Belajar Siswa SD/ MI".

\section{Pembahasan}

\section{A. Peran}

Soekanto menyebutkan bahwa "yang dimaksudkan dengan peran adalah pola tingkah laku yang diharapkan dari 
seseorang yang memangku status atau kedudukan tertentu" (Soekanto, 1992). Pengertian peran menurut Fahrizal, yaitu peran merupakan aspek dinamis kedudukan (status), apabila seseorang melaksanakan hak dan kewajibannya sesuai dengan kedudukannya, maka ia menjalankan suatu peranan (Fahrizal, 2011). Menurut Kamus Besar Bahasa Indonesia (KBBI), Peran adalah orang yang menjadi atau melakukan sesuatu yang khas, atau "perangkat tingkah laku yang diharapkan dimiliki oleh orang yang berkedudukan di masyarakat". Sehingga peran secara implisit menunjuk pada kekuatan dan peran lebih banyak menunjuk pada suatu fungsi, penyesuaian dan sebagai suatu proses. Peran adalah aktivitas yang diharapkan dapat mempengaruhi secara positif dari suatu kegiatan yang menentukan suatu proses keberlangsungan kegiatan.

Berdasarkan beberapa sumber di atas, dapat disimpulkan bahwa peran merupakan pemberian layanan kepada masyarkat (siswa SD/ MI) yang dapat mempengaruhi secara positif dari suatu proses keberlangsungan kegiatan yang ada, serta dapat meningkatkan minat belajar peserta didik.

\section{B. Lingkungan sekolah}

Lingkungan secara umum diartikan sebagai kesatuan dengan semua benda, daya, keadaan, dan mahluk hidup, termasuk manusia dan perilakunya, yang mempengaruhi kelangsungan perikehidupan dan kesejahteraan manusia serta mahluk hidup lainya (Munib, 2011). Lingkungan pendidikan pada hakikatnya merupakan sesuatu yang ada diluar individu maupun didalam individu (Siswoyo dkk, 2008). Lebih lanjut Siswoyo menyatakan bahwa " perguruan atau sekolah atau balai wiyata adalah lingkungan pendidikan yang mengembangkan dan meneruskan pendidikan anak menjadi warga negara yang cerdas, terampil dan bertingkah laku baik."

Lingkungan pendidikan adalah tempat seseorang memperoleh pendidikan secara langsung atau tidak langsung (Kadir, 2012). Artinya, 
lingkungan pendidikan merupakan segala sesuatu yang melingkupi proses berlangsungnya pendidikan. Lingkungan pendidikan yang dimaksud di sini adalah lingkungan belajar di sekolah tersebut. Sejalan dengan pendapatnya Ramadhani bahwa sekolah sebagai lembaga pendidikan formal harus menciptakan dan menyediakan lingkungan belajar yang kondusif dan sesuai dengan apa yang dibutukan siswa, sehingga proses belajar dapat berjalan dengan baik yang pada akhirnya akan meningkatkan minat belajar siswa (Ramadhani, 2018).

Lingkungan sekolah merupakan suatu kondisi yang ada di lembaga pendidikan formal yang melaksanakan program pengajaran, bimbingan, dan latiahan yang akan membantu siswa untuk mengembangankan potensi belajar siswa (Aditya, Riza Nur, 2019). Lingkungan sekolah merupakan salah satu faktor penting dalam mempengaruhi prestasi belajar peserta didik. Sukmadinata mengemukakan bahwa lingkungan sekolah juga memegang peranan penting bagi perkembangan belajar para siswanya (Sukmadinata, 2016).

Dari beberapa sumber di atas, dapat disimpulkan bahwa lingkungan sekolah merupakan lingkungan tempat berlangsungnya proses pendidikan. Didalam lingkungan sekolah para peserta didik menerima pendidikan untuk menjadi warganegara yang cerdas, terampil dan beringkah laku baik. Selain itu, sekolah juga berfungsi sebagai lembaga meningkatkan pola pikir peserta didik, karena di sekolah tersebut para peserra didik diajarkan bermacammacam ilmu pengetahuan, baik apek afektif, kognitif maupun psikomotor.

\section{Minat belajar}

Minat adalah suatu rasa lebih suka dan rasa keterikatan pada suatu hal atau aktivitas, tanpa ada yang menyuruh (Flora Siagian, 2015). Sedangkan menurut Lukmanul menjelaskan minat merupakan suatu ketertarikan seseorang untuk memperhatikan atau terlibat dalam aktivitas belajar secara aktif (Lukmatul, 
2009). Ditegaskan juga oleh Setiawati bahwa minat belajar merupakan aspek psikologi seseorang yang menampakkan diri dalam beberapa gejala, seperti: gairah, kemauan, perasaan suka untuk melakukan proses perubahan tingkah laku melalui berbagai kegiatan yang meliputi mencari pengetahuan dan pengalaman (Setiawati, Gusti Ayu Dewi, 2018).

Surait menjelaskan minat belajar adalah sebagai suatu aspek psikologi yang menampakkan diri dalam beberapa gejala seperti gairah, keinginan, perasaan suka melakukan proses perubahan tingkah laku melalui berbagai kegiatan yang meliputi mencari pengetahuan dan pengalaman (Surait, 2016). Artinya minat belajar adalah perhatian seseorang terhadap belajar yang ditunjukkan melalui keantusiasan, partisipasi dan keaktifan dalam belajar. Minat belajar akan muncul pada diri seseorang jika orang tersebut menyukai suatu hal, kegiatan, atau latihan yang disukai. Sehingga individu akan terdorong untuk terus melakukan kegiatan tersebut sehingga memiliki minat yang lebih untuk mempelajarinya.

Minat belajar diartikan juga sebagai motivasi yang muncul dari dalam diri seseorang untuk melakukan kegiatan atau latihan yang menyangkut kognitif, afektif dan psikomotorik secara sadar dan terus menerus sehingga terjadi perubahan tingkah laku.

Untuk mengetahui seberapa besar minat belajar siswa dapat diukur melalui kesukaan, ketertarikan, perhatian dan keterlibatan (Sudaryono, 2012). Kesukaan terlihat dari kegairahan siswa dalam mengikuti pelajaran Ketertarikan bisa diukur dari respon untuk menanggapi sesuatu. Perhatian bisa diukur apabila seseorang memiliki keseriusan selama proses pembelajaran berlangsung. Perhatian muncul didorong dengan munculnya rasa ingin tahu.

Ada beberapa macam cara yang dapat dilakukan oleh guru untuk membangkitkan minat belajar peserta didik yaitu: 1) membandingkan adanya suatu kebutuhan pada diri anak didik, 
sehingga dia rela belajar tanpa paksaan ;

2) menghubungkan bahan pelajaran yang diberikan dengan persoalan pengalaman yang dimiliki anak didik, sehingga anak didik mudah menerima bahan pelajaran, 3) memberikan kesempatan kepada anak didik untuk mendapatkan hasil belajar yang baik dengan cara menyediakan lingkungan belajar yang kreatif dan kondusif, 4) menggunakan berbagai macam bentuk dan teknik mengajar dalam konteks perbedaan individual anak didik (Djamarah, 2011).

\section{Faktor-faktor yang}

\section{Mempengaruhi Minat Belajar}

\author{
Syah menjelaskan beberapa \\ faktor yang mempengaruhi minat \\ belajar, yaitu :
}

1. Faktor intern, yang terdiri dari :

a. Aspek jasmani, mencangkup kondisi fisik/kesehatan jasmani dari individu.

b. Aspek psikologis (kejiwaan), menurut Sadirman, faktor psikologis, meliputi perhatian, pemahaman, tanggapan, fantasi, ingatan, berfikir, bakat dan motif.

2. Faktor ekstern, meliputi

a. Keluarga, meliputi hubungan antar keluarga, suasana lingkungan rumah dan keadaan ekonomi keluarga.

b. Sekolah, meliputi metode mengajar, kurikulum, sarana dan prasarana belajar, sumber-sumber belajar, media pembelajaran, hubungan siswa dengan temannya, pengar dan staf serta berbagai kegiatan kurikuler.

c. Lingkungan, meliputi hubungan dengan teman bergaul, kegiiatan dalam masyarakat dan lingkungan tempat tinggal (Syah, 2003).

Menurut Djamarah (2002) ada dua faktor yang mempengaruhi minat seseorang, yaitu : 
1. Faktor dari dalam (intrinsik) yaitu berarti bahwa sesuatu perbuatan memang diinginkan karena seseorang senang melakukannya. Disini minat datang dari diri orang itu sendiri. Orang tersebut senang melakukan perbuatan itu demi perbuatan itu sendiri.

2. Faktor dari luar (ekstrinsik) yaitu berarti bahwa sesuatu perbuatan dilakukan atas dasar dorongan atau paksaan dari luar. Orang melakukan kegiatan ini karena dorongan atau dipaksa dari luar (Djamarah, 2002).

Rifa'i menjelaskan bahwa ada enam faktor yang didukung oleh sejumlah teori psikologi dan penelitian terkait yang memiliki dampak substansial terhadap motivasi belajar peserta didik. Keenam faktor yang dimaksud yaitu: sikap, kebutuhan, rangsangan, afeksi, kompetensi, dan penguatan (Rifa'i, 2011).
Dari beberapa sumber di atas, dapat disimpulkan bahwa faktor-faktor yang mempengaruhi minat belajar pada umunya ada dua, yaitu dari dalam diri peserta didik dan dari luar peserta didik (lingkungan). Dari dalam diri peserta didik seperti kesukaan, bakat, ingatan, keadaan fisik dan lain-lain. Sedangkan dari luar peserta didik, seperti lingkungan keluarga, lingkungan masyarakat dan lingkungan sekolah.

\section{E. Peran lingkungan}

\section{sekolah terhadap minat belajar}

Siswa SD/MI merupakan bagian dari anggota masyarakat siswa dapat dipengaruhi oleh lingkungan sekitar. Oleh sebab itu, kondisi lingkungan yang sehat turut mempengaruhi minat belajar peserta didik. Menurut Uno pada umumnya, motif dasar yang bersifat pribadi muncul dalam tindakan individu setelah dibentuk oleh pengaruh lingkungan (Uno, 2014). Sehingga motif individu dalam melakukan sesuatu, dapat dikembangkan, diperbaiki, dan diperbaiki melalui belajar dan latihan. 
Dalam proses belajar haruslah memperhatikan apa yang dapat mendorong siswa agar dapat belajar dengan baik atau padanya mempunyai motif untuk berpikir dan memusatkan perhatian, merencanakan dan melaksanakan kegiatan yang berhubungan/ menunjang belajar (Slameto, 2013).

Minat belajar dapat ditanamkan kepada diri peserta didik dengan cara memberikan latihan-latihan atau kebiasaan-kebiasaan yang juga dipengaruhi oleh keadaan lingkungan. Guru harus mampu membangkitkan minat belajar peserta didik agar tujuan pembelajaran dapat tercapai dengan baik.

Menciptakan lingkungan sekolah yang kondusif untuk peserta didik merupakan salah satu usaha yang dilakukan guru membangkitkan minat belajar peserta didik. Memberikan latihan-latihan secara berkala kepada peserta didik dapat meningkatkan kesiapan dalam belajar. Kebiasaan- kebiasaan yang ditanamkan oleh guru dapat menciptakan kondisi lingkungan sekolah dan lingkungan belajar yang baik bagi peserta didik.

Peran lingkungan sekolah sangat memberikan dampak terhadap minat belajar siswa, sehingga lingkungan sekolah turut mempengaruhi tingkat keberhasilan belajar siswa. Faktor sekolah yang mempengaruhi belajar mencakup metode mengajar, kurikulum, relasi guru dengan siswa, relasi siswa dengan siswa, disiplin sekolah, alat pelajaran, waktu sekolah, standar pelajaran diatas ukuran, keadaan gedung, metode belajar, dan tugas rumah (Slameto, 2013). Sejalan dengan pernyataan Sardiman bahwa "mengajar merupakan suatu usaha penciptaan kondisi atau sistem lingkungan yang mendukung dan memungkinkan untuk berlangsungnya proses belajar" (Sardiman, 2009). Seorang guru harus mampu menyajikan variasi metode pembelajaran yang mampu membangkitkan hasrat ingin tahu siswa terhadap materi pembelajaran. 
Kegiatan belajar mengajar di kelas merupakan bagian dari lingkungan sekolah, maka untuk menciptakan suasan lingkungan sekolah yang kondusif, Seorang guru harus menguasai materi yang akan diajarkan kepada peserta didik, dan mampu menerangkan materi tersebut dengan jelas. Metode mengajar yang kurang tepat akan mempengaruhi hasil belajar peserta didik. Metode mengajar yang kurang tepat dapat terjadi karena guru kurang menguasai metode mengajar dan kurang menguasai bahan pembelajaran, sehingga berakibat pada merosotnya proses dan hasil belajar peserta didik. Guru harus menguasai berbagai macam metode mengajar dan menerapkanya secara variatif sehingga tujuan pembelajaran dapat tercapai secara efektif dan efisien. Sehingga peran lingkungan sekolah dapat berdampak positif terhadap minat belajar peserta didik. Maka sebaliknya jika kurang pemanfaatan lingkungan secara kondusif, maka pembelajaran akan terasa jenuh atau kurang berminat untuk belajar (Prameswari, Kd, Krisna,. I, Km, Ngurah Wiyasa, 2017).

\section{Kesimpulan}

Pendidikan merupakan usaha
sadar manusia untuk dapat
mengembangkan potensi dirinya melalui
proses pembelajaran, baik pendidikan
dasar, menengah ataupun perguruan
tinggi. Pendidikan dasar adalah jenjang
pendidikan yang melandasi jenjang
pendidikan menengah. Pendidikan dasar
dapat berbentuk sekolah dasar (SD) dan
madrasah ibtidaiyah (MI) atau yang
lainnya yang sederajat. Pendidikan di
SD/ MI sangatlah penting bagi peserta
didik, karena merupakan dasar
perkembangan pengetahuan yang
diperoleh peserta didik.

Faktor yang mempengaruhi tujuan pembelajaran bisa dicapai yantu faktor intern dan faktor ekstern. Faktor intern yang berasal dari dalam diri peserta didik, sedangkan faktor ekstern berasal dari luar peserta didik (lingkungan). Faktor intern yang besar pengaruhnya terhadap belajar adalah 
gen, motivasi, minat dan lain-lain. Sedangkan untuk faktor ekstern adalah faktor lingkungan belajar terutama lingkungan sekolah.

\section{Lingkungan sekolah teridiri} pendidik dan tenaga kependidikan, materi/ bahan ajar, teman-teman sekelas peserta didik serta lingkungan sekolah secara fisik (sarana dan prasarana). Terciptanya lingkungan sekolah yang baik sesuai dengan standarisasi pendidikan, maka akan meningkatkan minat belajar peserta didik dan mempermudah pelaksanaan pembelajaran yang kondusif. Sehingga tujuan pembelajaran dapat tercapai dengan baik dan lancar. Dapat ditarik kesimpulkan bahwa lingkungan sekolah dapat mempengaruhi secara positif dari suatu proses keberlangsungan kegiatan pembelajaran di sekolah, serta dapat meningkatkan minat belajar peserta didik.

Saran yang dapat disampaikan, kita sebagai pendidik baik guru, dosen ataupun tenaga kependidikan untuk mencapai tujuan pembelajaran dengan baik, maka salah satu yang harus kita perhatikan adalah minat belajar peserta didik. Tentunya untuk meningkatkan minat belajar peserta didik salah satunya harus menciptakan suasana lingkungan sekolah yang baik dan sesuai dengan kebutuhan pembelajaran.

\section{DAFTAR PUSTAKA}

Aditya, Riza Nur, dan S. M. (2019).

PENGARUH LINGKUNGAN

KELUARGA DAN SEKOLAH

TERHADAP MINAT THE

INFLUENCE OF THE FAMILY

AND SCHOOL ATMOSPHERE

ON THE INTEREST TO. Jurnal

Pendidikan Vokasional Teknik

Mesin, 7 No 1(19), 65-72.

Baharun, H. (2015). Penerapan

Pembelajaran Active Learning untuk Meningkatkan Hasil Belajar

Siswa di Madrasah. Jurnal

Pendidikan Pedagogik, 1(1), 34-

46. 
Djamarah, S. B. (2002). Strategi

Belajar Mengajar. Jakarta: Rineka Cipta.

Djamarah, S. B. (2011). Psikologi

Belajar. Jakarta: Rineka Cipta.

Fahrizal, S. (2011). Tinjauan Pustaka. Unila.

Fajri, Z. (2010). Pembelajaran

Kooperatif dengan Menerapkan

Teori Brunner Pokok Bahasan

Keliling dan Luas Bangun Datar

Kelas IVA SD Negeri Tamanan 2

Tahun Ajaran 2009/2010. Skripsi

tidak diterbitkan. Jember:

Universitas Jember.

Flora Siagian, R. E. (2015). Pengaruh

Minat dan Kebiasaan Belajar

Siswa terhadap Prestasi Belajar

Matematika. Formatif: Jurnal

Ilmiah Pendidikan MIPA, 2(2),

122-131.

https://doi.org/10.30998/formatif.v $2 \mathrm{i} 2.93$

Higgins, Steve. Elaine Hall, Kate Wall,

Pam Woolner, dan C. M. (2015).

The Impact of School

Environments: A literature review.
Retrieved from

http://128.240.233.197/cflat/news/

DCReport.pdf

Kadir, A. (2012). Dasar - Dasar

Pendidikan (Kencana Pr). Jakarta.

Kemdikbud. (2003). Sistem Pendidikan

Nasional. Retrieved from

http://dikdas.kemdikbud.go.id/wpcontent/uploads/2013/11/ uunomor-20-\%0Atahun-2003tentang-sistem-pendidikannasional.pdf. Diakses pada 13 November 2016 Pukul 08.20

Lukmatul, H. (2009). Perencanaan Pembelajaran. Bandung: Wacana Prima.

Munib, A. (2011). Pengantar Ilmu Pendidikan. Semarang: UPT MKU UNNES.

Prameswari, Kd, Krisna,. I, Km, Ngurah Wiyasa, N. N. G. (2017). Pengaruh Model Pembelajaran Course Review Horay (CRH) Berbantuan Lingkungan Sekolah terhadap Kompetensi Pengetahuan IPA Siswa Kelas V SD Gugus

Kompyang Sujana Kecamatan 
Denpasar Utara. E-Journal PGSD

Universitas Pendidikan Ganesha, 5 No 2, 1-11.

Ramadhani, D. (2018). PENGARUH

INTERAKSI GURU — SISWA

DAN LINGKUNGAN BELAJAR

TERHADAP MINAT BELAJAR

EKONOMI SISWA Diantyastuti

Ramadhani. Jurnal Pendidikan

Dan Ekonomi, 7(6), 524-532.

Rifa'i, A. dan C. T. A. (2011). Psikologi

Pendidikan. Semarang: UPT MKU

UNNES.

Sardiman. (2009). Interaksi dan

Motivasi Belajar Mengajar.

Jakarta: Rajawali Pers.

Setiawati, Gusti Ayu Dewi, D. N. B.

(2018). Pengaruh Penerapan

Model Pembelajaran Kooperatif

Terhadap Minat Belajar Biologi

Dengan Menggunakan Lingkungan

Pura Taman Ayun Sebagai Sumber

Belajar (Langkah Awal

Mengenalkan Profesi Cultural

Interpreter). Prosiding Seminar

Nasional Pendidikan Biologi,

(ISBN: 978, 186-190.
Slameto. (2013). Belajar dan FaktorFaktor yang Mempengaruhi. Jakarta: Rineka Cipta.

Soekanto. (1992). Sosiologi: Suatu Pengantar. Jakarta: PT. Raja Grafindo.

Sudaryono. (2012). Darar-Dasar Evaluasi Pembelajaran. Yokyakarta: Graha Ilmu.

Sukmadinata, N. S. (2016). Landasan Psikosologi Proses Pendidikan. Bandung: PT. Remaja Rosdakarya. Surait, E. D. (2016). Pengaruh minat belajar terhadap prestasi belajar matematika. Jurnal Formatif, 6(1), 35-43.

Suyono. (2011). Belajar dan Pembelajaran. Bandung: Re. Syah, M. (2003). Psikologi Pendidikan dengan Pendekatan Baru. Bandung: Remaja Rosdakarya. Uno, H. B. (2014). Teori Motivasi Dan Pengukuranya. Jakarta: Bumi Aksara. 